\section{Michigan Technological



Michigan Technological University Digital Commons @ Michigan Tech

\title{
Progress in Indium Gallium Nitride Materials for Solar Photovoltaic Energy Conversion
}

Dirk V. P. McLaughlin

Queen's University

Joshua M. Pearce

Michigan Technological University

Follow this and additional works at: https://digitalcommons.mtu.edu/materials_fp

\section{Recommended Citation}

McLaughlin, Dirk V. P., \& Pearce, Joshua M. (2013). Progress in Indium Gallium Nitride Materials for Solar Photovoltaic Energy Conversion. Metallurgical and Materials Transactions A-Physical Metallurgy and Materials Science, 44A(4), 1947-1954. http://digitalcommons.mtu.edu/materials_fp/9 


\title{
Progress in Indium Gallium Nitride Materials for Solar Photovoltaic Energy Conversion
}

\begin{abstract}
DIRK V.P. MCLAUGHLIN and JOSHUA M. PEARCE
The world requires inexpensive, reliable, and sustainable energy sources. Solar photovoltaic (PV) technology, which converts sunlight directly into electricity, is an enormously promising solution to our energy challenges. This promise increases as the efficiencies are improved. One straightforward method of increasing PV device efficiency is to utilize multi-junction cells, each of which is responsible for absorbing a different range of wavelengths in the solar spectrum. Indium gallium nitride $\left(\operatorname{In}_{x} \mathrm{Ga}_{1-x} \mathrm{~N}\right)$ has a variable band gap from 0.7 to $3.4 \mathrm{eV}$ that covers nearly the whole solar spectrum. In addition, $\operatorname{In}_{x} \mathrm{Ga}_{1-x} \mathrm{~N}$ can be viewed as an ideal candidate PV material for both this potential band gap engineering and microstructural engineering in nanocolumns that offer optical enhancement. It is clear that $\operatorname{In}_{x} \mathrm{Ga}_{1-x} \mathrm{~N}$ is an extremely versatile potential PV material that enables several known photovoltaic device configurations and multijunctions with theoretic efficiencies over 50 pct. This potential is driving immense scientific interest in the material system. This paper reviews the solar PV technology field and the basic properties of $\operatorname{In}_{x} \mathrm{Ga}_{1-x} \mathrm{~N}$ materials and PV devices. The challenges that remain in realizing a high-efficiency $\operatorname{In}_{x} \mathrm{Ga}_{1-x} \mathrm{~N}$ PV device are summarized along with paths for future work. Finally, conclusions are drawn about the potential for $\operatorname{In}_{x} \mathrm{Ga}_{1-x} \mathrm{~N}$ photovoltaic technology in the future.
\end{abstract}

DOI: $10.1007 / \mathrm{s} 11661-013-1622-1$

(c) The Minerals, Metals \& Materials Society and ASM International 2013

\section{INTRODUCTION}

GLOBAL civilization requires inexpensive, reliable, and sustainable energy sources. The lack of stability in fossil fuel prices, supply challenges, risks from nuclear power, and the growing environmental concerns on the combustion of fossil fuels is driving a renewed interest in developing solar photovoltaic (PV) devices, which convert sunlight directly into electricity and offer enormous potential as a source of sustainable energy ${ }^{[1]}$ Since 1990 , global solar PV module production has increased more than 500-fold from 46 megawatts (MW) to $23.5 \mathrm{GW}$ in 2010 ( $\$ 82$ billion), and grew last year to reach $28 \mathrm{GW}$ - all of which has radically reduced the costs. ${ }^{[2]}$ This growth is being driven by reduced costs and higher performance in solar cells on the market, which are now generally 10 to 20 pct efficient. However, in order to compete economically with fossil fuels in all markets in the current subsidy landscape, further decreases in the levelized cost of electricity from solar are needed. ${ }^{[3]}$ If this was to occur, the potential market would be in hundreds of billions of dollars. For example, consider recent work by Keiser that showed that at US\$3 per watt for complete PV systems - and some commercial projects are at this

DIRK V.P. MCLAUGHLIN, Graduate Student, is with the Department of Mechanical and Materials Engineering, Queen's University, Kingston ON, Canada. JOSHUA M. PEARCE, Professor, is with the Department of Materials Science \& Engineering, Michigan Technological University, 601 M\&M Building, 1400 Townsend Drive, Houghton, MI 49931-1295, and also with the Department of Electrical \& Computer Engineering, Michigan Technological University. Contact e-mail: pearce@mtu.edu

Manuscript submitted February 27, 2012.

Article published online February 1, 2013 level now-addressable electricity consumption rises to 440 billion $\mathrm{kWh}$, equivalent to over $300 \mathrm{GW}$ of capacity in the U.S. alone. ${ }^{[4]}$ Conventional (first generation) polycrystalline silicon (p-Si) and single-crystalline silicon (c-Si) solar cells have limited abilities to either improve performance and/or reduce costs further, ${ }^{[5,6]}$ although it should be noted that even c-Si-based PV is already competitive with fossil fuel-fired electricity in some markets. ${ }^{[3]}$ Second generation thin-film solar photovoltaic technology such as hydrogenated amorphous silicon (a-Si:H), copper indium gallium (di)selenide (CIGS), and cadmium telluride (CdTe) does have these abilities. Unfortunately, as these thin-film technologies evolve, their costs become progressively dominated by those of the constituent materials, in this case the top cover sheet and encapsulation, ${ }^{[7]}$ and thus further efficiency improvements are needed to completely dominate the conventional electricity market and enable large-scale replacement of fossil fuels. It should also be noted here that as current thin-film PV technologies have relatively low efficiencies as the costs of modules drop, the relative cost of the balance of systems (BOS) begins to dominate system price. A high-efficiency low-cost PV device would overcome this BOS cost challenge as the amount of racking in particular is determined by efficiency.

The most promising approach to further drive down costs for clean solar electricity is to copiously increase the conversion efficiency of solar cells, and one of the most promising techniques for improving PV efficiency is the use of multi-junction cells to absorb a wider energy range of incident photons. ${ }^{[6]}$ Indium gallium nitride $\left(\operatorname{In}_{x} \mathrm{Ga}_{1-x} \mathrm{~N}\right)$ is an ideal material candidate with theoretic efficiencies over 60 pct for multi-junction cells 
as its range of band gaps covers the solar spectrum: about $0.7 \mathrm{eV}$ for $\mathrm{InN}^{[8-15]}$ to $3.4 \mathrm{eV}$ for $\mathrm{GaN}^{[16-26]}$ depending on the relative indium content, $\mathrm{x}$. Although a debate reigned for some time on the nature of $\operatorname{InN}$, this is largely resolved ${ }^{[25]}$ and $\mathrm{GaN}$ in particular is well understood. In addition to band gap engineering, the PV device performance can be improved by engineering the microstructure of the material to increase the optical path length and provide light trapping. For this purpose, nanocolumns are candidates for the ideal microstructure as it has been shown that when their diameters are optimized, resonant behavior is observed. ${ }^{[27]}$ Furthermore, nanocolumns offer a reduction in strain and defect states and can improve flexibility and wear characteristics on the macroscale. ${ }^{[28,29]}$ In addition, the growth of $\operatorname{In}_{x} \mathrm{Ga}_{1-x} \mathrm{~N}$ nanocolumns has already been demonstrated on $\mathrm{SiO}_{2}$ using a plasma-assisted evaporation process that can in theory be scaled to $\mathrm{m}^{2}$ volume manufacturing needed for PV. ${ }^{[30]}$ Both single- and multijunction nanowire photovoltaic devices have already been demonstrated in silicon systems. ${ }^{[31,32]}$ In addition, InN nanowire solar cells have been demonstrated on $\mathrm{Si}$ substrates. ${ }^{[33]}$

Thus, it is clear that $\operatorname{In}_{x} \mathrm{Ga}_{1-x} \mathrm{~N}$ is an extremely versatile potential PV material that enables several photovoltaic device configurations. This paper will first review the solar photovoltaic technology field and the basic properties of $\operatorname{In}_{x} \mathrm{Ga}_{1-x} \mathrm{~N}$ materials and $\mathrm{PV}$ devices. The challenges that remain in realizing a high-efficiency $\mathrm{In}_{x} \mathrm{Ga}_{1-x} \mathrm{~N}$ PV device will be reviewed and future work will be outlined. Finally, conclusions will be drawn about the future of the $\operatorname{In}_{x} \mathrm{Ga}_{1-x} \mathrm{~N}$ photovoltaic technology.

\section{BACKGROUND ON PHOTOVOLTAIC TECHNOLOGY AND IN ${ }_{X} \mathrm{GA}_{1-X}$ N MATERIALS}

One of the greatest hindrances to reducing the cost of photovoltaic energy is the relatively low efficiencies of commercial solar modules, which translate into large $\$ / W$ costs. Crystalline silicon-based solar cells, which only have a single junction $(1.1 \mathrm{eV})$, have an indirect band gap and therefore require a considerable thickness of semiconductor material. Thus, c-Si PV is fundamentally limited in future reductions in the initial costs. The newer thin-film technologies (CdTe and CIGS) also use single-junction cells. In conventional single-junction cells, one of the primary energy loss mechanisms limiting the efficiency arises from the rapid thermalization of photoexcited carriers, particularly of those with energy well in excess of the single band gap. The most successful method of reducing this loss is to subdivide the broad solar emission spectrum into different energy ranges (colors) and to convert each range with a cell of a well-matched band gap to absorb that color. This spectral splitting can be obtained by stacking cells on top of one another, with the largest band gap cell closest to the sun. These stacked cells have already been successfully commercialized with up to three layers for terrestrial solar cells (e.g., a-Si:H cells from Uni-Solar, which unfortunately have relatively low efficiencies of $\sim 10$ pet due to poor material quality, resulting in the company's recent financial difficulties). Record-setting high efficiencies of 40.7 pct have been demonstrated using this approach on a triple-junction metamorphic $\mathrm{GaInP} / \mathrm{GaInAs} / \mathrm{Ge}$ cell under high concentration and 31.3 pet at 1 sun. ${ }^{[34]}$ Using a similar approach Solar Junction has pushed the current triple-junction record to 44 pct. The benefits of increased power output from a tandem stack is offset by increased system complexity if separate connections to individual cells must be made; so, tandems are generally operated as two terminal devices. For such cells connected in series, the current must be matched, just as for standard modules. This matching is achieved by controlling the band gap and thickness of each cell in the stack. The theoretic upper limit in efficiency of an infinite stack is 86.8 pct for direct- and 68.2 pct for diffuse-photovoltaic cells. ${ }^{[5]}$ Using conventional cells, the upper limit of the conversion efficiency of a single junction is 31 pct and the standard operating efficiencies of silicon-based solar cells are less than 20 pct, so there is obviously substantial room for improvement to capture all the potential energy from the sun. By adding junctions (as seen in Table I), the theoretic efficiencies increase substantially.

\section{A. Band gap Engineering}

One of the primary reasons that large number, multiband gap solar cells are not in widespread use is the difficulty in finding appropriate multiple band gap materials that are able to both function and be compatible during deposition due to lattice mismatch parameters. This has in part been overcome using metamorphic materials as demonstrated by the triplejunction cell discussed above, ${ }^{[34]}$ but are still limited due the potential to scale up such deposition methods. However, there is one emerging material family that has the capability of covering almost all of the usable solar emission range ( 0.5 to $3.0 \mathrm{eV})$ and that is the Group IIINitrides, specifically the alloy indium gallium nitride. The material properties of this alloy depend heavily on the ratio of indium $(x)$ to gallium $(1-x)$ in its composition. Most important to photovoltaic applications, by changing the material's indium content, the band gap of $\operatorname{In}_{x} \mathrm{Ga}_{1-x} \mathrm{~N}$ can be tuned from $0.7 \mathrm{eV}(\mathrm{InN}$; $x=1)$ to $3.4 \mathrm{eV}(\mathrm{GaN} ; x=0)$ which spans nearly the entire solar spectrum as discussed above. The ability to select the band gap in a controlled fashion from $0.7 \mathrm{eV}$ up to $3.4 \mathrm{eV}$ is ideal for high-efficiency solar cell applications as seen in Figure 1, which shows the band gap spread of $\operatorname{In}_{x} \mathrm{Ga}_{1-x} \mathrm{~N}$ as a function of In concentration on an AM1.5 spectrum. The band gap $\left(E_{\mathrm{g}}\right)$ has been determined using the composition-weighted average of the GaN and InN gaps using a "bowing" parameter, $b$ of 1.4 following

$$
E_{\mathrm{g}}(x)=x E_{\mathrm{g}}(\mathrm{InN})+(1-x) E_{\mathrm{g}}(\mathrm{GaN})-b x(1-x)
$$

The reference spectra $\left[\mathrm{W} / \mathrm{m}^{2} / \mathrm{nm}\right]$ (on the left $y$-axis) shown in blue were modeled providing the global 37 
Table I. Maximum Theoretic Efficiencies for Solar Cells of Varying Junctions ${ }^{[35]}$

\begin{tabular}{|c|c|c|c|c|c|}
\hline \multirow[b]{2}{*}{ Number of Junctions } & \multicolumn{4}{|c|}{ Optimum Band Gaps (eV) } & \multirow[b]{2}{*}{ Efficiency (pct) } \\
\hline & $E_{\mathrm{g} 1}$ & $E_{\mathrm{g} 2}$ & $E_{\mathrm{g} 3}$ & $E_{\mathrm{g} 4}$ & \\
\hline 1 & 1.31 & - & - & - & 31 \\
\hline 2 & 0.98 & 1.88 & - & - & 42.7 \\
\hline 3 & 0.83 & 1.45 & 2.26 & - & 49.1 \\
\hline 4 & 0.73 & 1.23 & 1.78 & 2.56 & 53 \\
\hline$\infty$ & - & - & - & - & 69 \\
\hline$\infty(\mathrm{w} /$ conc. $)$ & - & - & - & - & 86.8 \\
\hline
\end{tabular}

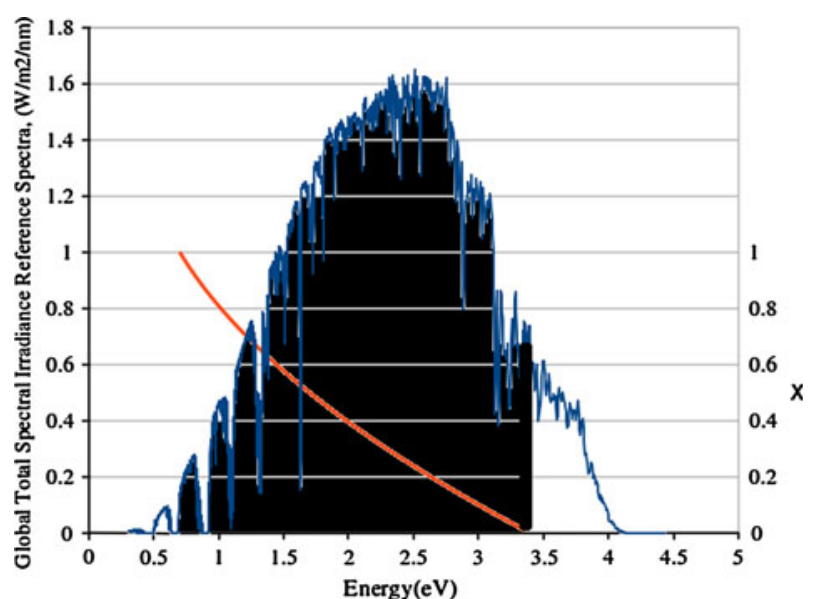

Fig. 1-The spectra $\left[\mathrm{W} / \mathrm{m}^{2} / \mathrm{nm}\right]$ (left $y$-axis) shown in blue were modeled using the SMARTS2 (version 2.9.2) Simple Model for Atmospheric Transmission of Sunshine of Gueymard. The data used for the Global 37 Deg Tilt: ASTM G-173 was converted from wavelength to $\mathrm{eV}$. The values of the In content $x$ are shown in the right $y$-axis (Color figure online).

Degree Tilt spectra for ASTM G-173. It was converted from wavelength to $\mathrm{eV}$. The values of the In content $x$ are shown in the right $y$-axis (red line). The black filled area of the spectra could be harvested efficiently from a multi-band gap $\operatorname{In}_{x} \mathrm{Ga}_{1-x} \mathrm{~N}$ PV device.

Just like its components InN and $\mathrm{GaN}$, wurtzite is the thermodynamically stable structure of $\operatorname{In}_{x} \mathrm{Ga}_{1-x} \mathrm{~N}$. This structure has a hexagonal close-packed lattice type with an $\mathrm{AB}$ atomic repeating pattern. However, under certain deposition conditions, $\operatorname{In}_{x} \mathrm{Ga}_{1-x} \mathrm{~N}$ can also form in the zinc-blende structure. ${ }^{[36]}$ This structure has a facecentered cubic lattice type with an $\mathrm{ABC}$ atomic repeating pattern.

\section{B. Flexibility in Photovoltaic Device Structure}

Research into using $\operatorname{In}_{x} \mathrm{Ga}_{1-x} \mathrm{~N}$ as an absorber in solar cells is still in its early stages, although a diverse collection of PV device structures has been fabricated and tested including $\operatorname{In}_{x} \mathrm{Ga}_{1-x} \mathrm{~N} p-i-n$ and $p-n$ homojunction cells, ${ }^{[37,38]} \operatorname{In}_{x} \mathrm{Ga}_{1-x} \mathrm{~N} / \mathrm{Si}$ hetereojunction, ${ }^{[39]}$ $\mathrm{In}_{x} \mathrm{Ga}_{1-x} \mathrm{~N} / \mathrm{GaN}$ heterostructure solar cells with $p$ - $n$, $p-i-n$, and nanorod/nanowire configurations, ${ }^{[40-46,48]}$ $\mathrm{In}_{x} \mathrm{Ga}_{1-x} \mathrm{~N}$ p-n junctions, ${ }^{[47,49]} \operatorname{In}_{x} \mathrm{Ga}_{1-x} \mathrm{~N}$ quantum well solar cells, ${ }^{[50-54]}$ and $\operatorname{In}_{x} \mathrm{Ga}_{1-x} \mathrm{~N}$ quantum dot PV. ${ }^{[55]}$ A comprehensive survey of the current performance of $\operatorname{In}_{x} \mathrm{Ga}_{1-x} \mathrm{~N}$-based PV has been compiled by Bhuiyan et al. ${ }^{[56]}$ However, $\operatorname{In}_{x} \mathrm{Ga}_{1-x} \mathrm{~N}$ films with low indium contents have been used commercially for light-emitting diodes (LEDs) in the green, blue, and violet wavelengths and are more technically advanced ${ }^{[57,58]}$ as are $\operatorname{In}_{x} \mathrm{Ga}_{1-x} \mathrm{~N}$-based lasers. ${ }^{[59-62]}$

\section{C. $I n_{x} G a_{1-x} N$ Advantages as a Photovoltaic Material}

As a member of the III-nitride alloy semiconductor group, $\mathrm{In}_{x} \mathrm{Ga}_{1-x} \mathrm{~N}$ possesses good optoelectronic properties that make it in theory well suited for thin-film multi-junction solar cells. ${ }^{[63,64]} \operatorname{In}_{x} \mathrm{Ga}_{1-x} \mathrm{~N}$ is a direct band gap semiconductor which means that during photon absorption, direct interband transitions can occur without the need of a phonon to conserve momentum. ${ }^{[36]}$ Typical of direct band gap semiconductors, $\operatorname{In}_{x} \mathrm{Ga}_{1-x} \mathrm{~N}$ also has a very high absorption coefficient on the order of $10^{5} \mathrm{~cm}^{-1}$ near the band edge. ${ }^{[65,66]}$ This indicates that 99 pct of photons above the band gap will be absorbed in the first $500 \mathrm{~nm}$ of the $\mathrm{In}_{x} \mathrm{Ga}_{1-x} \mathrm{~N}$ film. ${ }^{[43]}$ Since only a thin layer of material is needed for efficient absorption, not only are material costs minimized but also the distance that electrons are required to travel for extraction is kept short, thereby offering fewer opportunities for recombination. Thus, $\mathrm{In}_{x} \mathrm{Ga}_{1-x} \mathrm{~N}$ material systems have enormous promise as ultrahigh efficient solar cells. ${ }^{[67]}$ They also possess several other advantages besides the acceptable thin layer absorber and an ability to perform band gap engineering including the following:

(a) Bernardini and Fiorentini have shown insensitivity to high dislocation densities as the polarization and piezoelectric properties of the material introduce electric fields and surface dipoles that appear to counter the effects of dislocations in the crystalline form. ${ }^{[68,69]}$

(b) A consequence of the polarization is a strong band bending at the junctions that can reduce surface recombination velocities that enhance the performance of solar cells, ${ }^{[70]}$ although there can be problems with polarization. ${ }^{[71]}$

(c) $\mathrm{In}_{x} \mathrm{Ga}_{1-x} \mathrm{~N}$ has a low effective mass of charge carriers (electrons and holes).

(d) $\operatorname{In}_{x} \mathrm{Ga}_{1-x} \mathrm{~N}$ material possesses high peak and saturation velocities, ${ }^{[72]}$ which are important for lasers, ${ }^{[59-62]}$ but not as important for low-current devices like PV.

(e) $\operatorname{In}_{x} \mathrm{Ga}_{1-x} \mathrm{~N}$ material has high absorption coefficients, which overcome the low diffusion lengths. 
High absorption also enables the active absorber layer to be thin in the cell and thus a low material requirement, lower cost, and a better ecological footprint.

(f) High radiation tolerances have been observed indicating the $\mathrm{In}_{x} \mathrm{Ga}_{1-x} \mathrm{~N}$ material will have long-term reliability in harsh environments. ${ }^{[73]}$

(g) There is considerable technical co-development for LEDs and lasers that can be used to speed technical evolution of $\operatorname{In}_{x} \mathrm{Ga}_{1-x} \mathrm{~N}$ solar cells.

(h) $\mathrm{In}_{x} \mathrm{Ga}_{1-x} \mathrm{~N}$ solar cells do not contain toxic elements like arsenic, cadmium, or phosphorous.

The earliest success with a clear PV response was first seen in $2007,{ }^{[56]}$ yet $\operatorname{In}_{x} \mathrm{Ga}_{1-x} \mathrm{~N}$ is a rapidly emerging material system for solar photovoltaic cells with a surging international scientific interest. ${ }^{[4,56,74-76]}$ Most of the excellent work to date has been limited by the material quality, although recent investigations into $\mathrm{In}_{x} \mathrm{Ga}_{1-x} \mathrm{~N}$ single-junction PV devices have reported successful results in achieving significant photoresponses from experimental devices, ${ }^{[56,77]}$ and an $\operatorname{In}_{x} \mathrm{Ga}_{1-x} \mathrm{~N}$ multi-quantum well solar cell with a 5.95 pct efficiency under AM1.5 has already been produced. ${ }^{\left[{ }^{[8]}\right.}$

\section{Advanced Microstructures for $\operatorname{In}_{x} G a_{1-x} N P V$}

In addition to band gap engineering from In concentration in $\operatorname{In}_{x} \mathrm{Ga}_{1-x} \mathrm{~N}$ materials, $\operatorname{In}_{x} \mathrm{Ga}_{1-x} \mathrm{~N}$ is also capable of being deposited with advanced microstructures, which enable optical enhancement within the absorber layer itself. This in theory decreases the necessary thickness of the absorber layer, thus reducing processing time, volume of material, and presumably cost per unit power. The ideal microstructures have been identified as nanocolumns as discussed above. There are several approaches to this type of solar cell including creating junctions axially, radially, or at the substrate interface of nanocolumn growth. Thus, in an attempt to improve crystal quality, significant research is being conducted into the growth of $\operatorname{In}_{x} \mathrm{Ga}_{1-x} \mathrm{~N}$ nanowires and nanocolumns. By relaxing the inherent strain involved in the epitaxial growth of lattice mismatched layers, nanocolumns significantly reduce threading dislocations that plague typical $\mathrm{In}_{x} \mathrm{Ga}_{1-x} \mathrm{~N}$ films. ${ }^{[79]}$ As a result, the non-radiative recombination that plagues a cell's short-circuit current can be made nearly non-existent. ${ }^{[80]}$ This strain-relaxed growth also improves indium incorporation and decreases the tendency toward phase separation. In fact, single-crystal nanowires grown using low-temperature halide chemical vapor deposition (CVD) showed no phase separation with indium contents ranging from 0 to 60 pct. $^{[81]}$

However, since nanocolumns greatly increase the ratio of surface area to volume compared to planar films, nanocolumnar films have a far higher number of surface states. This is one drawback of growing nanocolumns as these states can trap photogenerated carriers, thereby reducing the performance of a solar cell. This is particularly important for $\operatorname{In}_{x} \mathrm{Ga}_{1-x} \mathrm{~N}$ nanocolumns as the alloy naturally has a large density of surface defects. In order to minimize this surface recombination, a high-band gap window layer is often used to passivate the surface. For this purpose, an $n$-type GaN window layer has been shown to improve the open-circuit voltage and fill factor of an $\operatorname{In}_{x} \mathrm{Ga}_{1-x} \mathrm{~N}$ solar cell. ${ }^{[76]}$

A variety of techniques has been used to grow $\mathrm{In}_{x} \mathrm{Ga}_{1-x} \mathrm{~N} / \mathrm{GaN}$ nanocolumnar structures: radio-frequency molecular beam epitaxy (MBE) ${ }^{[82-84]}$ plasmaassisted MBE, ${ }^{[85]} \mathrm{CVD},{ }^{[81,86]}$ hydride vapor phase epitaxy (HVPE) ${ }^{[80,87]}$ and plasma-assisted evaporation. ${ }^{[30,88,89]}$ Regardless of the deposition technique, the growth of $\operatorname{In}_{x} \mathrm{Ga}_{1-x} \mathrm{~N}$ nanocolumns is most dependent on three key deposition parameters: temperature, growth rate, and the III-V ratio. Low temperatures of $823 \mathrm{~K}\left(\sim 550^{\circ} \mathrm{C}\right)$, high growth rates, and heavily nitrogen-rich conditions are found to promote the formation of the non-thermodynamically stable nanocolumns. ${ }^{[81,90]}$

The physical mechanism for nanocolumnar growth is typically the vapor-liquid-solid (VLS) process initiated by the "Ga balling" effect. ${ }^{[91-95]}$ In this mechanism, Ga liquid droplets nucleate on the substrate or buffer surface and establish liquid-solid interfaces. $\mathrm{In}_{x} \mathrm{Ga}_{1-x} \mathrm{~N}$ selectively grows from these $\mathrm{GaN}$ islands upward along the c-axis. While most $\operatorname{In}_{x} \mathrm{Ga}_{1-x} \mathrm{~N}$ columnar growth is self-catalyzed by the gallium atoms, some authors report the need for another metal catalyst such as gold to initiate nanocolumn growth. ${ }^{[86]} \mathrm{A}$ similar but slightly different growth mechanism for $\operatorname{In}_{x} \mathrm{Ga}_{1-x} \mathrm{~N}$ nanorods was also reported by $\mathrm{Wu}$ et al. ${ }^{[82]}$ This nanorod growth was observed in situ using a high-temperature transmission electron microscope (TEM). In this process, $\mathrm{In}_{x} \mathrm{Ga}_{1-x} \mathrm{~N}$ is first grown epitaxially until the critical layer is reached. At this point, film relaxation occurs leading to the formation of islands, and $\mathrm{In}_{x} \mathrm{Ga}_{1-x} \mathrm{~N}$ nanorods then begin to nucleate on these rough islands and grow vertically. The diameter of the nanorods depends on the size of these islands. If growth continues long enough, these nanorods will meet and coalesce. This particular type of growth may be beneficial for PV applications as it enables depositing a top contact without concern for shunting.

\section{CHALLENGES FOR HIGH-EFFICIENCY IN $_{X} \mathbf{G A}_{1-X} \mathbf{N}$ PV DEVICES}

As research of $\operatorname{In}_{x} \mathrm{Ga}_{1-x} \mathrm{~N}$ is still in its early stages, there remain a number of technical challenges that must be overcome before its implementation in high-efficiency devices predicted by theory. ${ }^{[56]}$ Despite enormous potential, real $\operatorname{In}_{x} \mathrm{Ga}_{1-x} \mathrm{~N}$ PV devices are currently limited to 6 pct efficiencies. The most important challenge lies in the growth of $\operatorname{In}_{x} \mathrm{Ga}_{1-x} \mathrm{~N}$ films over the entire compositional range ( $x=0$ to 1$)$. There are two common problems: an inability to grow high-quality low-defect crystalline films and the difficulty in achieving a homogeneous indium composition throughout the material. The following sections will discuss the factors causing these difficulties and the methods being tested to overcome them. 


\section{A. Crystal Quality}

The III-nitride alloys are difficult to grow in large bulk crystals due to the lack of substrate materials with closely matching lattice constants. ${ }^{[96]}$ Depositing material on a substrate with a mismatched lattice constant causes the growing film to be strained (increasing strain with increasing mismatch). This effect can result in a tilting of planes with respect to the misoriented substrate and causes defects such as dislocations, cracks, and pin holes to form. ${ }^{[97]} \operatorname{In}_{x} \mathrm{Ga}_{1-x} \mathrm{~N}$ films suffer from lattice mismatch with the most common substrates such as sapphire ( $\mathrm{GaN}$ mismatch of 16 pct) and silicon $(\mathrm{GaN}$ and InN mismatch of 9 and 7 pct, respectively). ${ }^{[36,79]}$

However, in addition to substrate mismatches, the growth of high-quality $\operatorname{In}_{x} \mathrm{Ga}_{1-x} \mathrm{~N}$ is also hindered by lattice constant differences between $\mathrm{InN}$ and $\mathrm{GaN}$. Various authors have placed this large mismatch at between 10 and 13 pct. ${ }^{[66,96-98]}$ As a result of this lattice mismatch, it has proven very difficult to avoid crystalline deterioration in $\operatorname{In}_{x} \mathrm{Ga}_{1-x} \mathrm{~N}$ films with indium contents between 20 and 80 pct. ${ }^{[25,98]}$ Compared to other III-nitride alloys, epitaxially grown $\operatorname{In}_{x} \mathrm{Ga}_{1-x} \mathrm{~N}$ films have an extremely high threading dislocation density of up to $10^{10}$ dislocations $/ \mathrm{cm}^{2} .^{[99,100]}$ Despite this, In${ }_{x} \mathrm{Ga}_{1-x} \mathrm{~N}$ exhibits strong electroluminescence (EL) and photoluminescence (PL) peaks, which explains the success of $\operatorname{In}_{x} \mathrm{Ga}_{1-x} \mathrm{~N}$ LEDs. ${ }^{[101]}$ However, the large threading dislocation densities still cause the performance of $\operatorname{In}_{x} \mathrm{Ga}_{1-x} \mathrm{~N}$ PV to suffer from elevated leakage current and non-radiative recombination rates. ${ }^{[45]}$

\section{B. Indium Incorporation and Segregation}

In addition to increasing dislocation densities and other defects, the InN and GaN lattice mismatch also creates a solid phase miscibility gap in $\operatorname{In}_{x} \mathrm{Ga}_{1-x} \mathrm{~N}$ films. ${ }^{[102]}$ This causes indium to segregate out of the bulk $\operatorname{In}_{x} \mathrm{Ga}_{1-x} \mathrm{~N}$, thereby reducing the compositional homogeneity and subsequently the quality of the crystal. ${ }^{[103]}$ The difference in formation enthalpy between $\mathrm{InN}$ and $\mathrm{GaN}$ also contributes to this phase separation phenomenon. ${ }^{[102]}$ Indium tends to segregate out from the $\mathrm{In}_{x} \mathrm{Ga}_{1-x} \mathrm{~N}$ film in two forms: at the surface and in small clusters within the $\operatorname{In}_{x} \mathrm{Ga}_{1-x} \mathrm{~N}$ bulk.

At the surface of the growing film, InN evaporates away at a much higher rate than GaN. This effect is a result of a higher vapor pressure of InN relative to $\mathrm{GaN}$ and the thermodynamic instability of $\mathrm{InN}$ at high growth temperatures $>823 \mathrm{~K}\left(>550{ }^{\circ} \mathrm{C}\right) .{ }^{[104,105]}$ Consequently, many researchers have found it difficult to grow In-rich $\operatorname{In}_{x} \mathrm{Ga}_{1-x} \mathrm{~N}$ films. ${ }^{[25]}$ There are a few techniques employed that improve this indium incorporation. Low growth temperatures $<823 \mathrm{~K}\left(<550{ }^{\circ} \mathrm{C}\right)$ and pressures suppress the evaporation of indium by reducing the impact of InN's thermodynamic stability and vapor pressure differences, respectively. ${ }^{[101]}$

Growth rate is another deposition parameter that plays a significant role in indium incorporation and crystal quality. $\operatorname{In}_{x} \mathrm{Ga}_{1-x} \mathrm{~N}$ films grown at higher growth rates (above 1.0 angstrom/second) are generally found to have higher indium contents. ${ }^{[25,101]}$ This occurs because the incoming gallium atoms quickly form a new layer and trap the indium adatoms (surface atoms) before they can evaporate off the surface of the film. ${ }^{[97]}$

However, while higher growth rates and lower growth temperatures and pressures improve indium incorporation in $\operatorname{In}_{x} \mathrm{Ga}_{1-x} \mathrm{~N}$ films, they also cause deterioration in the quality of the material through indium clustering and compositional inhomogeneity. ${ }^{[5]}$ Higher growth rates and lower temperatures reduce the lateral mobility of the indium adatoms, which leads to an uneven composition in the growing film. ${ }^{[106]}$ Once the clusters reach a critical size, they become thermodynamically stable and can act as sinks for incoming indium atoms. These clusters present a problem to $\mathrm{In}_{x} \mathrm{Ga}_{1-x} \mathrm{~N}$ photovoltaic performance as they have been shown to act as efficient recombination centers for excitons. ${ }^{[107]} \mathrm{A}$ number of photoluminescence (PL) studies of $\mathrm{In}_{x} \mathrm{Ga}_{1-x} \mathrm{~N}$ films have found emission peaks at a constant energy $(2.3$ to $2.5 \mathrm{eV})$ insensitive to varying indium contents. ${ }^{[108,109]}$ This strong emission peak provides evidence for the existence of an In-rich phase which, while only representing a small fraction of the film's volume, dominates the emission mechanism of the film. Various authors have reported the presence of In-rich quantum wells and quantum dots in these clusters. ${ }^{[80,107]}$ One author attributes the PL emission peaks to 15 -nm-diameter quantum dot structures with an indium content of $x=0.56 .^{[108]}$ It is clear the intense PL emissions reported are a direct product of radiative recombination in these In-rich clusters, which would be expected due to their lower band gap relative to the surrounding bulk matrix. These efficient recombination centers will significantly reduce the carrier lifetimes, which in turn reduce the $\operatorname{In}_{x} \mathrm{Ga}_{1-x} \mathrm{~N}$ solar cell short-circuit current, thus crippling the efficiency of a solar cell.

The use of high V-III flux ratios (nitrogen to indium/ gallium) is one growth technique that has shown to improve indium incorporation without reducing the quality of the film. ${ }^{[25]}$ A large nitrogen flux is believed to provide additional nitrogen bonding sites for indium atoms that might otherwise evaporate away or segregate out of the bulk $\mathrm{In}_{x} \mathrm{Ga}_{1-x} \mathrm{~N}$ and form a separate indium phase ${ }^{[110]}$ Despite this, the difficulty in growing high-quality In-rich films remains the biggest challenge to the development of efficient $\mathrm{In}_{x} \mathrm{Ga}_{1-x} \mathrm{~N}$ solar cells. New growth techniques and conditions are required to develop more compositionally homogeneous, highly crystalline $\operatorname{In}_{x} \mathrm{Ga}_{1-x} \mathrm{~N}$ films with improved photovoltaic properties.

In order to reduce the negative effect of substrate lattice mismatch with the growing $\operatorname{In}_{x} \mathrm{Ga}_{1-x} \mathrm{~N}$ films, it is common practice to use a buffer layer between the substrate and film. This layer has an intermediate lattice constant to ease the transition from substrate to film which can reduce compressive straining during growth. ${ }^{[97,100]} \mathrm{A}$ thin GaN buffer layer has been shown to improve the structural and optical properties of $\operatorname{In}_{x} \mathrm{Ga}_{1-x} \mathrm{~N}$ films. ${ }^{[30,36,86,96,111]}$ In addition, there is considerable work on the growth of $\operatorname{In}_{x} \mathrm{Ga}_{1-x} \mathrm{~N}$ nanowires and nanocolumns to overcome the challenges as detailed in Section II-D.

\section{Doping}

Most solar cells utilize a $p-n$ or $p-i-n$ structure to separate photocarriers of opposite charge within the 
device. However, the $p$-type doping of $\operatorname{In}_{x} \mathrm{Ga}_{1-x} \mathrm{~N}$ has proven very difficult due to the extremely high density of defects (e.g., dangling bonds) and low position of the conduction band edge below the Fermi level stabilization energy. ${ }^{[48]}$ This combination of factors makes intrinsic $\operatorname{In}_{x} \mathrm{Ga}_{1-x} \mathrm{~N}$ an $n$-type semiconductor, in particular at the higher indium composition levels. As a result, the most successful $p$-type doping has been limited to a few recent reports of $\operatorname{In}_{x} \mathrm{Ga}_{1-x} \mathrm{~N}$ films with low indium $(x<0.5)$ compositions,${ }^{[48,105,112]}$ although it should be pointed out that even $p$-type doping of InN has been demonstrated. ${ }^{[113]}$ As with GaN, magnesium $(\mathrm{Mg})$ is the element chosen for this $p$-type doping of $\mathrm{In}_{x} \mathrm{Ga}_{1-x} \mathrm{~N}$.

Since the surfaces of $\operatorname{In}_{x} \mathrm{Ga}_{1-x} \mathrm{~N}$ films have the highest density of defects and strongest electron accumulation, it is also the region most resistant to $p$-type doping. ${ }^{[67]} \mathrm{Chen}$ reports on $\operatorname{In}_{x} \mathrm{Ga}_{1-x} \mathrm{~N}$ films up to $x=0.3$ with confirmed bulk $p$-type polarity that still exhibits strong $n$-type Hall measurements due to the surface electron accumulation. ${ }^{[48]}$ This represents a significant challenge to the development of $\operatorname{In}_{x} \mathrm{Ga}_{1-x} \mathrm{~N}$ solar cells as this surface accumulation could possibly represent a parasitic conductivity path between $\mathrm{p}$ and $\mathrm{n}$ contacts. ${ }^{[48]}$ Additionally, while not found in Chen's $\operatorname{In}_{x} \mathrm{Ga}_{1-x} \mathrm{~N}$ layers, there is evidence indicating that the addition of $\mathrm{Mg}$ atoms can affect crystal growth and cause phase separation in $\mathrm{In}_{x} \mathrm{Ga}_{1-x} \mathrm{~N}$ films at high $\mathrm{Mg}$ concentrations. ${ }^{[111]}$ Most of the $\mathrm{Mg}$ atoms were found to be inactive and residing in defect sites within the crystal. In order to lower the levels of $\mathrm{Mg}$ dopant required (and reduce phase separation), a focus on improving $\operatorname{In}_{x} \mathrm{Ga}_{1-x} \mathrm{~N}$ crystalline quality and minimizing defect sites is suggested.

\section{CONCLUSIONS}

$\mathrm{In}_{x} \mathrm{Ga}_{1-x} \mathrm{~N}$ offers the potential for ultrahigh efficient multi-junction solar cells to provide for the global society's energy needs. Both the wide range of band gap engineering and the microstructural engineering in nanocolumns make $\operatorname{In}_{x} \mathrm{Ga}_{1-x} \mathrm{~N}$ an extremely versatile potential PV material that enables several known PV device configurations and multi-junctions with theoretic efficiencies over 50 pct. Although recent investigations into $\mathrm{In}_{x} \mathrm{Ga}_{1-x} \mathrm{~N}$ single-junction PV devices have reported successful results in achieving significant photoresponses from experimental devices, a better understanding of minority carrier lifetimes, recombination rates, the nature of defect states, and how to take advantage of the materials' microstructural flexibility is necessary for taking this material system from a curiosity to a contender in the race for mass-scale solar electric production. Further work is needed in improving crystal quality, fabricating the materials with systems that can be scaled up to the meter squared scale, illuminating the problems associated with In segregation, and obtaining p-doped materials with high In content. $\operatorname{In}_{x} \mathrm{Ga}_{1-x} \mathrm{~N}$ offers a great potential, but significant further research is needed to realize that potential. This potential is driving intense scientific interest in this material system as a PV absorber, which is clearly accelerating over time.

\section{REFERENCES}

1. J.M. Pearce: Futures, 2002, vol. 34, pp. 663-74.

2. A. Jäger-Waldau: PV Status Report 2011: Research, Solar Cell Production and Market Implementation of Photovoltaics, European Commission, DG Joint Research Centre, Institute for Energy and Transport, Renewable Energy Unit, Ispra, VA, Italy. http://re.jrc.ec.europa.eu/refsys/.

3. K. Branker, M.J.M. Pathak, and J.M. Pearce: Renew. Sust. Energ. Rev., 2011, vol. 15, pp. 4470-82.

4. R. Keiser: $P V$ Tech, 2011. http://www.pv-tech.org/guest_blog/ 100gw_of_demand_and_the_coming_inflection_point_in_the_us_ solar_market.

5. M.A. Green: Third Generation Photovoltaics: Advanced Solar Energy Conversion, 1st ed., Springer, Berlin, 2003.

6. M.A. Green: Third Generation Photovoltaics: Advanced Solar Energy Conversion, 2nd ed., Springer, Berlin, 2005, pp. 59-69.

7. J.M. Woodcock, H. Schade, H. Maurus, B. Dimmler, J. Springer, and A. Ricaud: in Proc. 14th European PV Solar Energy Conference, Barcelona, pp. 857-60.

8. V.Y. Davydov, A.A. Klochikhin, R.P. Seisyan, V.V. Emtsev, S.V. Ivanov, F. Bechstedt, J. Furthmuller, H. Harima, A.V. Mudryi, J. Aderhold, O. Semchinova, and J. Graul: Phys. Status Solidi B, 2002, vol. 229, p. R1.

9. Y. Saito, H. Harima, E. Kurimoto, T. Yamaguchi, N. Teraguchi, A. Suzuki, T. Araki, and Y. Nanishi: Phys. Status Solidi B, 2002, vol. 234, pp. 796-800.

10. T. Matsuoka, H. Okamoto, M. Nakao, H. Harima, and E. Kurimoto: Appl. Phys. Lett., 2002, vol. 81, pp. 1246-48.

11. J. Wu, W. Walukiewicz, K.M. Yu, J.W. Ager, III, E.E. Haller, H. Lu, W.J. Schaff, Y. Saito, and Y. Nanishi: Appl. Phys. Lett., 2002, vol. 80, pp. 3967-69.

12. J. Wu, W. Walukiewicz, W. Shan, K.M. Yu, J.W. Ager, S.X. Li, E.E. Haller, H. Lu, and W.J. Schaff: J. Appl. Phys., 2003, vol. 94 (7), pp. 4457-60.

13. B. Arnaudov, T. Pashkova, P.P. Paskov, B. Magnusson, E. Valcheva, B. Monemar, H. Lu, W.J. Schaff, H. Amano, and I. Akasaki: Phys. Rev. B, 2004, vol. 69, pp. 115216-21.

14. W. Walukiewicz, S.X. Li, J. Wu, K.M. Yu, J.W. Ager, III, E.E. Haller, H. Lu, and W.J. Schaff: J. Cryst. Growth, 2004, vol. 269, pp. 119-27.

15. B. Monemar, P.P. Paskov, and A. Kasic: Superlatt. Microstruct., 2005, vol. 38, pp. 38-56.

16. H. Morkoc, S. Strite, B.G. Gao, M.E. Lin, B. Sverdlov, and M. Burns: J. Appl. Phys. Rev., 1994, vol. 76, pp. 1363-98.

17. S.N. Mohammad and H. Morkoc: Prog. Quantum Electron., 1996, vol. 20, pp. 361-525.

18. S.P. Denbaar: Proc. IEEE, 1997, vol. 85, pp. 1740-46.

19. O. Ambacher: J. Phys. D Appl. Phys., 1998, vol. 31, pp. 26532710 .

20. S.J. Pearton, J.C. Zolper, R.J. Shul, and F. Ren: J. Appl. Phys., 1999, vol. 86, pp. 1-78.

21. S.J. Pearton, F. Ren, A.P. Zhang, and K.P. Lee: Mater. Sci. Eng. $R, 2000$, vol. 30, pp. 55-212.

22. R.F. Davis, A.M. Roskowski, E.A. Preble, J.S. Speck, B. Heying, J.A. Feitas, E.R. Glaser, Jr., and W.E. Carlos: Proc. IEEE, 2002, vol. 90, pp. 993-1005.

23. M. Higashiwaki, T. Inushima, and T. Matsui: Phys. Status Solidi $B, 2003$, vol. 240, pp. 417-20.

24. M.A. Reshchikov and H. Morkoc: J. Appl. Phys., 2005, vol. 97, pp. 061301-96.

25. F.K. Yam and Z. Hassan: Superlatt. Microstruct., 2008, vol. 43 (1), pp. 1-23.

26. Y. Pan, T. Wang, K. Shen, T. Peng, K. Wu, W. Zhang, and C. Liu: J. Cryst. Growth, 2010, vol. 313, pp. 16-19.

27. L. Cao, J.S. White, J.S. Park, J.A. Schuller, B.M. Clemens, and M.L. Brongersma: Nat. Mater., 2009, vol. 8, pp. 643-47.

28. Z. Fan, H. Razavi, J. Do, A. Moriwaki, O. Ergen, Y.L. Chueh, P.W. Leu, J.C. Ho, T. Takahashi, L.A. Reichertz, S. Neale, K. Yu, M. Wu, J.W. Ager, and A. Javey: Nat. Mater., 2009, vol. 8 (8), pp. 648-53.

29. L. Tsakalakos, J. Balch, J. Fronheiser, B.A. Korevaar, O. Sulima, and J. Rand: Appl. Phys. Lett., 2007, vol. 91, pp. 233117/ $1-233117 / 3$

30. S. Keating, M.G. Urquhart, D.V.P. McLaughlin, and J.M. Pearce: Cryst. Growth Des., 2011, vol. 11 (2), pp. 565-68. 
31. M.D. Kelzenberg, D.B. Turner-Evans, B.M. Kayes, A. Michael, M.C. Putnam, N.S. Lewis, and H.A. Atwater: Nano Lett., 2008, vol. 8 (2), pp. 710-14.

32. T.J. Kempa, B. Tian, D.R. Kim, J. Hu, X. Zheng, and C.M. Lieber: Nano Lett., 2008, vol. 8 (10), pp. 3456-60.

33. H.P.T. Nguyen, Y.L. Chang, I. Shih, and Z. Mi: IEEE J. Sel. Topics Quantum Electron., 2011, vol. 17 (4), pp. 1062-69.

34. R.R. King, D.C. Law, K.M. Edmondson, C.M. Fetzer, G.S. Kinsey, H. Yoon, R.A. Sherif, and N.H. Karam: Appl. Phys. Lett., 2007, vol. 90, pp. 183516-19.

35. A. Marti and G. Araujo: Sol. Energy Mater. Sol. Cells, 1996, vol. 43, pp. 203-22.

36. M. Anani, H. Abid, Z. Chama, C. Mathieu, A. Sayede, and B. Khelifa: Microelectron. J., 2007, vol. 38 (2), pp. 262-66.

37. X.M. Cai, S.W. Zeng, and B.P. Zhang: Appl. Phys. Lett., 2009 vol. 95 (17), p. 173504.

38. C. Boney, I. Hernandez, R. Pillai, D. Starikov, A. Bensaoula, M. Henini, M. Syperek, J. Misiewicz, and R. Kudrawiec: Physica Status Solidi (c), 2011, vol. 8 (7-8), pp. 2460-62.

39. L.A. Reichertz, I. Gherasoiu, K.M. Yu, V.M. Kao, W. Walukiewicz, and J.W. Ager: Appl. Phys. Express, 2009, vol. 2 (12), pp. 122202-1-122202-3.

40. C.J. Neufeld, N.G. Toledo, S.C. Cruz, M. Iza, S.P. DenBaars, and U.K. Mishra: Appl. Phys. Lett., 2008, vol. 93, pp. 143502-1143502-3.

41. J.R. Lang, C.J. Neufeld, C.A. Hurni, S.C. Cruz, E. Matioli, U.K. Mishra, and J.S. Speck: Appl. Phys. Lett., 2011, vol. 98 (13), pp. 131115-1-131115-3.

42. E. Matioli, C. Neufeld, M. Iza, S.C. Cruz, A.A. Al-Heji, X. Chen, R.M. Farrell, S. Keller, S. DenBaars, U. Mishra, S. Nakamura J. Speck, and C. Weisbuch: Appl. Phys. Lett., 2011, vol. 98, pp. 021102-1-021102-3.

43. O. Jani, I. Ferguson, C. Honsberg, and S. Kurtz: Appl. Phys. Lett., 2007, vol. 91, pp. 132117-1-132117-3.

44. D.Y. Zhang, X.H. Zheng, L.J. Tang, J.R. Dong, H. Wang, and H. Yang: IEEE Electron Device Lett., 2010, vol. 31 (12), pp. $1422-24$.

45. R.Y. Horng, S.T. Lin, Y.L. Tsai, M.T. Chu, W.Y. Liao, M.H. Wu, R.M. Lin, and Y.C. Lu: IEEE Electron. Device Lett., 2009, vol. 30, pp. 724-26.

46. X. Zheng, R.H. Horng, D.S. Wuu, M.T. Chu, W.Y. Liao, M.H. Wu, R.M. Lin, and Y.C. Lu: Appl. Phys. Lett., 2008, vol. 93, pp. 261108-1-261108-3.

47. E. Trybus, O. Jani, S. Burnham, I. Ferguson, C. Honsberg, M. Steiner, and W.A. Doolittle: Phys. Status Solidi C, 2008, vol. 5 (6), pp. 1843-45.

48. X. Chen, K.D. Matthews, D. Hao, W.J. Schaff, and L.F. Eastman: Phys. Status Solidi A, 2008, vol. 205, pp. 1103-05.

49. C. Boney, I. Hernandez, R. Pillai, D. Starikov, A. Bensaoula, M Henini, M. Syperek, J. Misiewicz, and R. Kudrawiec: IEEE Phot. Spec. Conf., 2010, pp. 003316-003321.

50. R. Dahal, B. Pantha, J. Li, Y.J. Lin, and H.X. Jiang: Appl. Phys. Lett., 2009, vol. 94, pp. 063505-1-063505-3.

51. R. Dahal, J. Li, K. Aryal, J.Y. Lin, and H.X. Jiang: Appl. Phys. Lett., 2010, vol. 97, pp. 073115-1-073115-3.

52. I.M. Pryce, D.D. Koleske, A.J. Fischer, and H.A. Atwater: Appl. Phys. Lett., 2010, vol. 96 (15), pp. 153-156.

53. K.Y. Lai, G.J. Lin, Y.L. Lai, Y.F. Chen, and J.H. He: Appl. Phys. Lett., 2010, vol. 96 (8), pp. 081103-1-081103-3.

54. M.J. Jeng, Y.L. Lee, and L.B. Chang: J. Phys. D Appl. Phys., 2009, vol. 42 (10), p. 105101.

55. Y.-J. Lee, M.-H. Lee, C.-M. Cheng, and C.-H. Yang: Appl. Phys. Lett., 2011, vol. 98 (26), pp. 263504-1-263504-3.

56. A. Bhuiyan, K. Sugita, A. Hashimoto, and A. Yamamoto: IEEE J. of Photovoltaics, 2012, vol. 2, pp. 276-93.

57. Y. Kawakami, S. Suzuki, A. Kaneta, M. Funato, A. Kikuchi, and K. Kishino: Appl. Phys. Lett., 2006, vol. 89, pp. 163124-1163124-3.

58. A. Laubsch, M. Sabathil, J. Baur, M. Peter, and B. Hahn: IEEE Trans. Electron. Devices., 2010, vol. 57 (1), pp. 79-87.

59. N. Trivellin, M. Meneghini, E. Zanoni, K. Orita, M. Yuri, T. Tanaka, D. Ueda, and G. Meneghesso: IEEE International Reliability Physics Symposium, 2010, 2010, pp. 1-6.

60. D. Sizov, R. Bhat, and C.-E. Zah: J. Lightwave Technol., 2012, vol. 30 (5), pp. 679-99.
61. J.W. Raring, E.M. Hall, M.C. Schmidt, C. Poblenz, B. Li, N. Pfister, D.F. Feezell, R. Craig, J.S. Speck, S.P. DenBaars, and S. Nakamura: Proc. SPIE, 2010, vol. 7602, p. 760218.

62. J.W. Raring, E.M. Hall, M.C. Schmidt, C. Poblenz, B. Li, N. Pfister, D. Kebort, Y.-C. Chang, D.F. Feezell, R. Craig, J.S. Speck, S.P. Denbaars, and S. Nakamura: Proc. SPIE, 2010, vol. 7686, p. 76860L

63. Q.A.H. Al-Naser, H.W. Hilou, and A.F. Abdulkader: ISECS International Colloquium on Computing, Communication, Control, and Management, 2009, vol. 1, pp. 373-78.

64. H. Hamzaoui, A.S. Bouazzi, and B. Rezig: Sol. Energy Mater. Sol. Cells, 2005, vol. 87, pp. 595-603.

65. V.Y. Davydov, A.A. Klochikhin, V.V. Emtsev, D.A. Kurdyukov, S.V. Ivanov, V.A. Vekshin, F. Bechstedt, J. Furthmuller, J. Aderhold, J. Graul, A.V. Mudryi, H. Harima, A. Hashimoto, A. Yamamoto, and E.E. Haller: Phys. Status Solidi B, 2002, vol. 234 (3), pp. 787-95.

66. Y. Sato and S. Sato: Thin Solid Films, 1995, vol. 261, pp. 8789.

67. S. Nishimura, K. Terashima, and H. Nagayoshi: IEEE Photo. Spec. Conf., 2005, pp. 725-27.

68. V. Fiorentini and F. Bernardini: Phys. Status Solidi B, 1999, vol. 216 (1), pp. 391-98.

69. F. Bernardini and V. Fiorentini: Phys. Rev. B, 2001, vol. 64, pp. $085207 / 1-085207 / 7$.

70. O. Jani, C. Honsberg, Y. Huang, J.O. Song, I. Ferguson, G. Namkoong, E. Trybus, A. Doolittle, and S. Kurtz: IEEE 4th World Conference on Photovoltaic Energy Conversion: Conference Record, 2006, pp. 20-25.

71. J.J. Wierer, A.J. Fischer, and D.D. Koleske: Appl. Phys. Lett., 2010, vol. 96 (5), pp. 051107-1-051107-3.

72. Y. Nanishi, Y. Saito, and T. Yamaguchi: Jpn. J. Appl. Phys., 2003, vol. 15 (42), pp. 2549-59.

73. J. Wu, W. Walukiewicz, K.M. Yu, W. Shan, J.W. Ager, E.E. Haller, H. Lu, W.J. Schaff, W.K. Metzger, and S. Kurtz: J. Appl. Phys., 2003, vol. 94 (10), pp. 6477-82.

74. T. Yamaguchi, C. Morioka, K. Mizuo, M. Hori, T. Araki, Y. Nanishi, and A. Suzuki: IEEE International Symposium on Compound Semiconductors: Post-Conference Proceedings, 2003, pp. 214-19.

75. C. Yang: PhysStatus Solidi A, 2007, vol. 204 (12), pp. 4288-91.

76. O. Jani, B. Jampana, M. Mehta, M. Yu, I. Ferguson, R. Opila, and C. Honsberg: 33rd IEEE Photovoltaic Specialists Conference, 2008, pp. 1-4.

77. S.W. Zeng, B.P. Zhang, J.W. Sun, J.F. Cai, C. Chen, and J.Z. Yu: Semicond. Sci. Technol., 2009, vol. 24, p. 055009.

78. B.W. Liou: Thin Solid Films, 2011, vol. 520 (3), pp. 1084-90.

79. F.R. Hu, K. Ochi, Y. Zhao, and K. Hane: Phys. Status Solidi C, 2007, vol. 4, pp. 2338-41.

80. H.M. Kim, H. Lee, S.I. Kim, S.R. Ryu, T.W. Kang, and K.S. Chung: Phys. Status Solidi B, 2004, vol. 241, pp. 2802-05.

81. T. Kuykendall, P. Ulrich, S. Aloni, and P. Yang: Nat. Mater., 2007, vol. 6, pp. 951-56.

82. K.M. Wu, Y. Pan, and C. Liu: Appl. Surf. Sci., 2009, vol. 255 (13-14), pp. 6705-09.

83. H. Sekiguchi, T. Nazakato, A. Kikuchi, and K. Kishino: J. Cryst. Growth, 2007, vol. 300 (1), pp. 259-62.

84. A. Kikuchi, K. Yamano, M. Tada, and K. Kishino: Phys. Status Solidi B, 2004, vol. 241 (12), pp. 2754-58.

85. A.P. Vajpeyi, A.O. Ajagunna, K. Tsagaraki, M. Androulidaki, and A. Georgakilas: Nanotechnology, 2009, vol. 20 (32), 325605.

86. X.M. Cai, F. Ye, S.Y. Jing, D.P. Zhang, P. Fan, and E.Q. Xie: J. Alloy Compd., 2009, vol. 467 (1-2), pp. 472-76.

87. H.M. Kim, Y.C. Cho, D.Y. Kim, T.Y. Kang, and K.S. Chung: AIP Conference Proceedings, 2005, vol. 772 (1), pp. 1515-16.

88. M. Einav, D.V.P. McLaughlin, and J.M. Pearce: ISPlasma 2011 Proceedings, 2011, P3-087A-LN.

89. D.V.P. McLaughlin and J.M. Pearce: Mater. Sci. Eng. B, 2012, vol. 177 (2), pp. 239-44.

90. E. Calleja, M.A. Sanchez-Garcia, F.J. Sanchez, F. Calle, F.B. Naranjo, E. Munoz, U. Jahn, and K. Ploog: Phys. Rev. B, 2000, vol. 62 (24), pp. 16826-34.

91. E.A. Stach, P.J. Pauzauskie, T. Kuykendall, J. Goldberger, R. He, and P. Yang: Nano Lett., 2003, vol. 3, pp. 867-69.

92. Y. Wu and P.J. Yang: Am. Chem. Soc., 2001, vol. 123, pp. 3165 66. 
93. T. Kuykendall, P. Pauzauskie, Y. Zhang, J. Goldberger, D. Sirbuly, J. Denlinger, and P. Yang: Nat. Mater., 2004, vol. 3 (8), pp. 524-28.

94. J. Ristić, M.A. Sanchez-Garcia, E. Calleja, J. Sanchez-Paramo, J.M. Calleja, U. Jahn, and K.H. Ploog: Phys. Status Solidi A, 2002, vol. 192, pp. 60-66.

95. S. Guha, N.A. Bojarczuk, M.A.L. Johnson, and J.F. Schetzina: Appl. Phys. Lett., 1999, vol. 75, pp. 463-65.

96. T. Takeuchi, H. Takeuchi, S. Sota, H. Sakai, H. Amano, and I. Akasaki: Jpn. J. Appl. Phys., 1997, vol. 36, pp. L177-79.

97. M. Leszczynski, R. Czernecki, S. Krukowski, M. Krysko, G. Targowski, P. Prystawko, J. Plesiewicz, P. Perlin, and T.J. Suski: J. Cryst. Growth, 2011, vol. 318, pp. 496-99.

98. M. Gartner, C. Kruse, M. Modreanu, A. Tausendfreund, C Roder, and D. Hommel: Appl. Surf. Sci, 2006, vol. 253 (1), pp. 254-57.

99. C.A. Parker, J.C. Robers, S.M. Bedair, M.J. Reed, S.X. Liu, and N.A. El-Masry: Appl. Phys. Lett., 1999, vol. 75 (18), pp. 2776-78.

100. N. Faleev, B. Jampana, O. Jani, H. Yu, R. Opila, I. Ferguson, and C. Honsberg: Appl. Phys. Lett., 2009, vol. 95 (5), pp. $051915-$ 1-051915-3.

101. S. Chichibu, T. Azuhata, T. Sota, and S. Nakamura: Appl. Phys. Lett., 1997, vol. 70 (21), pp. 2822-24.

102. L.S. Chuah, Z. Hassan, and H.A. Hassan: Microelectron. Int., 2008, vol. 25 (2), pp. 3-8.

103. X. Sun, W.B. Liu, D.S. Jiang, Z.S. Liu, L.L. Wang, H. Wang, J.J. Zhu, L.H. Duan, Y.T. Wang, D.G. Zhao, S.M. Zhang, and H.J. Yang: Phys. D Appl. Phys., 2008, vol. 41, p. 165108.
104. M.R. Correia, S. Pereira, E. Alves, and B. Arnaudov: Superlattice Microstruct., 2006, vol. 40 (4-6), pp. 452-57.

105. C.A. Chang, T.Y. Tang, P.H. Chang, N.C. Chen, and C.T. Liang: Jpn. J. Appl. Phys., 2007, vol. 46 (5A), pp. 2840-43.

106. A. Sohmer, J. Off, H. Bolay, V. Harle, V. Syganow, J.S. Im, V. Wagner, F. Adler, A. Hangleiter, A. Dornen, F. Scholz, D. Brunner, O. Ambacher, and H. Lakner: MRS Int. J. N. S. R., 1997, vol. 2 (13-15), p. 14.

107. O. Husberg, A. Khartchenko, D.J. As, K. Lischka, E. Silveira, O.C. Noriega, J.R.L. Fernandez, and J.R. Leite: Phys. Status Solidi C, 2003, vol. 0 (1), pp. 293-97.

108. O. Husberg, A. Khartchenko, D.J. As, H. Vogelsang, T. Frey, D. Schikora, K. Lischka, O.C. Noriega, A. Tabata, and J.R. Leite: Appl. Phys. Lett., 2001, vol. 79 (9), pp. 1243-45.

109. D.G. Pacheco-Salazar, J.R. Leite, F. Cerdeira, E.A. Meneses, S.F. Li, D.J. As, and K. Lischka: Semicond. Sci. Technol., 2006, vol. 21 (7), pp. 846-51.

110. P. Waltereit, O. Brandt, K.H. Ploog, M.A. Tagliente, and L. Tapfer: Phys. Status Solidi B, 2001, vol. 228 (1), pp. 49-53.

111. P. Schley, R. Goldhahn, A.T. Winzer, G. Gobsch, V. Cimalla, O. Ambacher, H. Lu, W.J. Schaff, M. Kurouchi, Y. Nanishi, M. Rakel, C. Cobet, and N. Esser: Phys. Rev. B, 2007, vol. 75 (20), p. 205204.

112. M. Horie, K. Sugita, A. Hashimoto, and A. Yamamoto: Sol. Energy Mater. Sol. C., 2009, vol. 93, pp. 1013-15.

113. R.E. Jones, K.M. Yu, S.X. Li, W. Walukiewicz, J.W. Ager, E.E. Haller, H. Lu, and W.J. Schaff: Phys. Rev. Lett., 2006, vol. 96 (12), pp. 125505-08 
Reproduced with permission of the copyright owner. Further reproduction prohibited without permission. 